\title{
Pengaruh Substitusi Tepung Buah Mangrove Jenis Lindur (Bruguiera gymnorrhiza) terhadap Kualitas Mie Basah
}

\section{The Effect of Lindur (Bruguiera gymnorrhiza) Mangrove Fruit Flour Substitution On The Quality of Wet Noodles}

\author{
Ratnawaty Fadilah, Program Studi Pendidikan Teknologi Pertanian, Universitas Negeri \\ Makassar. Email: ratnamangrove@ gmail.com \\ Ratna Sari, Program Studi Pendidikan Teknologi Pertanian, Universitas Negeri Makassar. \\ Email: ratnasarirahman32@gmail.com \\ Andi Sukainah, Program Studi Pendidikan Teknologi Pertanian, Universitas Negeri \\ Makassar. Email: andisukainah@yahoo.com
}

\begin{abstract}
Abstrak
Penelitian ini bertujuan untuk mengetahui bagaimana pengaruh substitusi tepung buah mangrove jenis lindur (Bruguiera gymnorrhiza) terhadap kualitas mie yang dihasilkan. Penelitian ini menggunakan metode eksperimen dengan rancangan percobaan Rancangan Acak lengkap (RAL) yang terdiri dari 4 perlakuan yaitu (K: Tepung Terigu 100\% + Tepung buah lindur 0\%, A: Tepung Terigu 80\% + Tepung buah lindur 20\%, B: Tepung Terigu $70 \%+$ Tepung buah lindur 30\%, C: Tepung Terigu 60\% + Tepung buah lindur 40\%). Data hasil pengamatan dianalisis menggunakan analisis sidik ragam (ANOVA) kemudian dilanjutkan dengan uji Duncan. Hasil penelitian menunjukkan bahwa perlakuan substitusi tepung buah mangrove jenis lindur (B. gymnorrhiza) memberikan pengaruh nyata terhadap kadar air, abu, protein, lemak, karbohidrat dan hasil organoleptik yaitu rasa, warna, tekstur, aroma dengan perlakuan terbaik berdasarkan Metode Perbandingan Eksponensial (MPE) adalah perlakuan A (Tepung terigu 80\% + Tepung Lindur 20\%) dengan kadar air 57.35\%, kadar abu $0.42 \%$, kadar protein $6.28 \%$, kadar lemak $1.16 \%$, kadar karbohidrat $35.18 \%$ dan uji organoleptik meliputi rasa 3.07 (suka), warna 3.27 (suka), aroma 3.00 (suka) dan tekstur 3.20 (suka).
\end{abstract}

Kata Kunci : Substitusi, Tepung Terigu, Tepung Lindur, Mie Basah

\begin{abstract}
This study aims to determine how the effect of the substitution of lindur mangrove flour (Bruguiera gymnorrhiza) on the quality of the noodles produced. This study used an experimental method with a completely randomized design trial (CRD) consisting of 4 treatments namely (K: $100 \%$ wheat flour $+0 \%$ lindur flour, A: $80 \%$ wheat flour $+20 \%$ lindur flour, B: $70 \%$ wheat flour $+30 \%$ lindur flour, C: wheat flour $60 \%+$ lindur flour $40 \%$ ). Observation data were analyzed using analysis of variance (ANOVA) and then followed by Duncan's test. The results showed that the treatment of substituted mangrove fruit flour $(B$. gymnorrhiza) affected the water content, ash, protein, fat, carbohydrates and organoleptic result there are taste, color, texture, aroma with the best treatment based on the Exponential Comparison Method (MPE) is treatment A (wheat flour 80\% + lindur flour 20\%) with a water content of $57.35 \%$, ash content of $0.42 \%$, protein content of $6.28 \%$, fat content of $1.16 \%$, carbohydrate content of $35.18 \%$ and organoleptic taste 3.07 (likes), color 3.27 (likes), aroma 3.00 (likes) and texture 3.20 (likes).
\end{abstract}

Keywords: Substitution, wheat flour, lindur flour, noodles 


\section{Latar Belakang}

Buah lindur (Bruguiera gymnorrhiza) adalah salah satu buah dari jenis tumbuhan mangrove yang cukup banyak ditemukan di wilayah perairan nusantara. Penyebaran buah lindur yaitu di daerah tropis Afrika Selatan dan Timur, Madagaskar, Asia Tenggara dan Selatan (termasuk Indonesia dan negara di kawasan Malaysia), sampai Timur Laut Australia, Mikronesia, Polinesia dan Kepulauan Ryukyu (Duke dan James 2006).

Pemanfaatan buah lindur untuk memenuhi kebutuhan pangan di Indonesia masih sangat terbatas penggunaannya. Teknik pengolahan buah lindur juga masih sederhana, kebanyakan buah lindur di beberapa tempat dikonsumsi oleh masyarakat pesisir dengan cara dicampurkan dengan nasi atau sagu. Olahan buah lindur tersebut biasanya dijadikan sebagai makanan tambahan bahkan terkadang dijadikan sebagai bahan pangan utama. Buah ini termasuk bahan yang memiliki kadar air yang cukup tinggi sehingga mudah membusuk. Sehingga seiring berjalannya waktu, buah ini mulai diolah menjadi tepung untuk menambah umur simpan.

Pemanfaatan buah lindur menjadi tepung didasarkan bahwa buah lindur mengandung karbohidrat yang cukup tinggi sehingga dapat diolah menjadi sumber tepung baru. Buah lindur memiliki rendemen $18.940 \%$, karbohidrat $82.092 \%$, protein $5.597 \%$, lemak $1.797 \%$, amilosa $18.476 \%$, serat kasar $8.701 \%$, abu $1.609 \%$ (Sulistyawati dkk, 2012). Buah mangrove jenis lindur (B. gymnorrhiza) yang secara tradisional diolah menjadi kue, dicampur dengan nasi atau dimakan langsung dengan bumbu kelapa (Sadana, 2007). Selain itu buah mangrove jenis lindur ini juga dapat dimanfaatkan sebagai tepung karena memiliki kandungan karbohidrat yang cukup tinggi, serta tekstur tepung lindur mirip dengan tekstur tepung terigu, akan tetapi warnanya lebih gelap dibandingkan tepung terigu.

Indonesia merupakan salah satu negara dengan masyarakat yang paling gemar mengonsumsi mie. Mie sudah menjadi seperti makanan kedua setelah nasi karena kandungan karbohidrat yang tinggi dan dapat digunakan sebagai bahan pangan alternatif karena kandungan gizi mie tidak kalah baiknya dengan beras, dimana bahan baku utamanya adalah tepung terigu (Astina, 2007). Mie basah adalah mie mentah yang sebelum dipasarkan mengalami perebusan dalam air mendidih lebih dahulu, jenis mie ini memiliki kadar air sekitar 52 \% (Koswara, 2009). Mie merupakan produk pangan yang paling sering dikonsumsi oleh sebagian besar masyarakat baik sebagai makanan sarapan maupun sebagai selingan (Juniawati, 2003).

Mie basah pada umumnya dibuat dari bahan baku berupa terigu. Tingkat konsumsi penduduk indonesia terhadap terigu saat ini sangat tinggi. Ketergantungan indonesia terhadap terigu impor menyebabkan harga terigu di pasar domestik masih terbilang tinggi karena dipengaruhi oleh harga dan ketersediaan gandum di pasar internasional. Salah satu upaya untuk membangun ketahanan pangan yaitu mengurangi impor terigu dengan cara mengembangkan bahan-bahan alternatif pengganti terigu sehingga mampu mengurangi ketergantungan impor terigu.

Berdasarkan hal tersebut maka buah lindur dapat dijadikan sebagai upaya substitusi tepung untuk mengurangi impor terigu di Indonesia. Selain itu buah lindur juga dapat digunakan sebagai alternatif pengembangan pangan fungsional karena 
memiliki kandungan serat yang cukup tinggi. Salah satu pengolahan tepung buah lindur adalah pengolahan menjadi mie. Dalam upaya diversifikasi pangan, mie dapat dikategorikan sebagai salah satu komoditi pangan substitusi karena dapat berfungsi sebagai bahan pangan pokok (Juniawati, 2003). oleh karena itu dalam penelitian ini dilakukan substitusi tepung buah mangrove jenis lindur dalam pembuatan mie basah untuk mengurangi penggunaan tepung terigu sebagai bahan baku dalam pembuatan mie. Penelitian ini bertujuan untuk mengetahui pengaruh substitusi tepung buah mangrove jenis lindur (B. gymnorrhiza) terhadap kualitas mie yang dihasilkan.

\section{Bahan dan Metode}

Penelitian ini menggunakan metode eksperimen dengan Rancangan Acak Lengkap (RAL) yang terdiri dari 4 perlakuan (K: Tepung Terigu 100\% + Tepung Lindur 0\%, A: Tepung Terigu $80 \%$ + Tepung Lindur 20\%, B: Tepung Terigu $70 \%+$ Tepung Lindur 30\%, C: Tepung Terigu 60\% + Tepung Lindur 40\%).

\section{Waktu dan Tempat}

Penelitian ini dilaksanakan pada bulan April - Juni 2019 di Laboratorium Program Studi Pendidikan Teknologi Pertanian untuk pembuatan tepung lindur dan produk mie basah dan hasil produk dianalisis di Laboratorium Kimia Politeknik Pertanian Negeri Pangkajene Kepulauan.

\section{Alat dan bahan}

Peralatan yang digunakan dalam pembuatan tepung lindur (B. gymonorrhiza) yaitu Cabinet dryer, timbangan, pisau, irisan keripik, baskom, tirisan, talenan, ayakan 80 mesh, sarung tangan, blender dan wadah plastik ukuran sedang. Alat pembuatan mie yaitu baskom, alat penggiling mie, pisau, sendok saring, kompor, panci, dan gas elpiji. Alat yang digunakan untuk analisis kimia cawan petri, oven listrik, desikator, neraca analitik dan spatula baja, cawan porselen, tanur, penjepit, tabung kjeldal (Bucci), Lemari Asam, Destilator, pipet tetes, erlenmeyer, Labu ukur $250 \mathrm{ml}$ (Pyrex), Buret, statif, soxhlet, tabung ekstraksi soxhlet, pendingin balik, penangas air, kertas saring kasar, pipet volume (HG) $10 \mathrm{ml}$, pipet volume 5 $\mathrm{ml}$, bola hisap (Merienfiel).

Bahan yang digunakan dalam penelitian ini adalah tepung lindur dimana buah lindur diperoleh dari Mangrove Center Bulonu Desa Binaga Kecamatan Sendana Kabupaten Majene. tepung terigu, telur, garam, CMC (Carboxymethyl cellulose) dan air. Bahan yang digunakan untuk analisis adalah $\mathrm{H} 2 \mathrm{SO} 4, \mathrm{NaOH}$, kertas saring, petroleum eter, alkohol 96\%, tablet Kjedahl, HCL, K2SO4, dan akuades.

\section{Prosedur Penelitian}

\section{Pembuatan Tepung Buah Lindur (Modifikasi Hamzah, 2017)}

Proses pembuatan tepung buah lindur yaitu sortasi dan pembersihan, pencucian, pengupasan, penimbangan, pengecilan ukuran menggunakan irisan keripik, perendaman dengan air selama 24 jam, pengeringan dengan cabinet dryer suhu $56^{\circ} \mathrm{C}$ selama 18 jam dan dilakukan proses penghalusan dengan menggunakan blender. Setelah proses penghalusan, tepung buah lindur disaring menggunakan ayakan 80 mesh untuk mengasilkan partikel yang lebih halus dengan ukuran yang sama. 


\section{Pembuatan Mie Basah (Modifikasi Astawan, 2006)}

Proses pembuatan mie basah dilakukan dengan menimbang masingmasing tepung terigu dan tepung lindur untuk formula $\mathrm{K}$ sebesar : $100 \%: 0 \%, \mathrm{~A}$ : $80 \%$ : $20 \%$, B: $70 \%$ : 30\%, dan C: $60 \%$ : $40 \%$. Masing- masing formula dicampur dengan bahan tambahan seperti garam $1 \mathrm{gr}$, air 10 gr, telur 25 gr dan CMC (Carboxy Methyl Cellulose) 1 gr, kemudian dilakukan pengulenan selama 15 menit sehingga diperoleh adonan yang kalis. Adonan dipipihkan dengan alat pencetak mie sambil ditaburi tepung terigu agar tidak lengket satu sama lainnya. Untaian mie yang dihasilkan lalu direbus pada suhu $85^{\circ} \mathrm{C}$ selama 2 menit, dan didinginkan pada suhu ruang.

Mie basah kemudian dianalisis yang meliputi kadar air, kadar abu, kadar protein, kadar lemak, kadar karbohidrat serta uji hedonik. Pengamatan uji hedonik dilakukan dengan cara memberikan penilaian terhadap mie basah dengan skala (1) tidak suka, (2) agak suka, (3) suka, (4) sangat suka, (5) amat sangat suka. Parameter uji hedonik meliputi rasa, warna, aroma dan tekstur. Pada pengujian ini menggunakan 25 panelis yang tidak terlatih.

\section{Teknik Analisis Data}

Teknik analisis data yang digunakan meliputi uji persyaratan analisis yang terdiri dari uji normalitas dan uji homogenitas. Apabila data yang diperoleh bersifat normal dan homogen maka akan dilanjutkan dengan analisis uji statistik sidik ragam ANOVA menggunakan Rancangan Acak Lengkap (RAL). Jika hipotesis diterima maka dilakukan uji lanjut, uji lanjut yang digunakan adalah uji Duncan (DMRT) pada taraf signifikan $\alpha=$ 0,05. Data diolah dengan menggunakan perangkat SPSS Versi 22.

\section{Hasil dan Pembahasan}

Hasil analisis kadar air, kadar abu, kadar lemak, kadar protein, kadar karbohidrat, kadar amilosa dan $\mathrm{HCN}$ tepung buah lindur yang digunakan dapat dilihat pada Tabel 1.

\begin{tabular}{lr}
\multicolumn{2}{c}{ Tabel 1. Kandungan Tepung Lindur } \\
\hline \multicolumn{1}{c}{ Komponen } & Jumlah \\
\hline Kadar air (\%) & 10.30 \\
Kadar abu (\%) & 1.30 \\
Kadar lemak (\%) & 1.41 \\
Kadar protein (\%) & 4.10 \\
Kadar karbohidrat (\%) & 82.87 \\
Amilosa (\%) & 18.35 \\
Asam Sianida/HCN (ppm) & 4.83 \\
\hline
\end{tabular}

Sumber: Hasil Penelitian, 2019

\section{Analisis Kimia}

\section{Kadar Air}

Kadar air merupakan salah satu faktor yang sangat berpengaruh terhadap penurunan mutu produk pangan. Semakin rendah kadar air, maka semakin lambat pertumbuhan mikroorganisme sedangkan bahan pangan tersebut dapat tahan lama. Sebaliknya semakin tinggi kadar air semakin cepat mikroorganisme berkembang biak, sehingga proses pembusukan akan berlangsung lebih cepat (Winarno, 2002). 


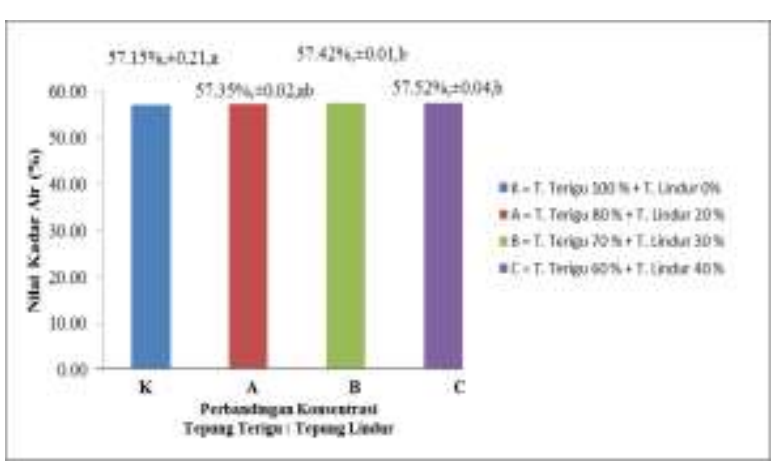

Gambar 1. Rerata Kadar Air Mie Basah

Hasil analisis sidik ragam menunjukkan bahwa perlakuan substitusi tepung lindur memberikan pengaruh sangat nyata terhadap kadar air mie basah. Gambar 1 . menunjukkan bahwa kadar air mie basah yang dihasilkan berkisar antara $57.15 \%$ sampai dengan $57.52 \%$. Kadar air tertinggi diperoleh dari perlakuan $60 \%$ terigu dengan $40 \%$ tepung lindur (C) yaitu 57.52\%, namun tidak berbeda nyata terhadap perlakuan $70 \%$ terigu dengan $30 \%$ lindur (B) yaitu $57.42 \%$ dan perlakuan $80 \%$ terigu dengan $20 \%$ tepung lindur (A) yaitu $57.35 \%$. Kadar air terendah diperoleh pada perlakuan kontrol $100 \%$ terigu dengan $0 \%$ tepung lindur (A) yaitu $57.15 \%$.

Hal ini menunjukkan kadar air substutusi tepung lindur mengalami peningkatan seiring dengan penambahan tepung lindur. Hal ini disebabkan karena adanya perbedaan konsentrasi tepung lindur dan tepung terigu dimana semakin banyak proporsi tepung buah lindur yang ditambahkan maka akan semakin tinggi kadar air dari mie basah. Meningkatnya kadar air disebabkan karena buah lindur memiliki kandungan serat yang relatif cukup tinggi yaitu sebesar 12,70\% (Sulistyawati et al., 2012), semakin tinggi kadar serat maka semakin banyak air yang terperangkap di dalamnya. Serat dapat mengikat air melalui gugus hidroksil sehingga lebih banyak air yang terperangkap dalam jaringan. Serat juga tersusun atas dinding seperti selulosa dimana selulosa memiliki gugus hidroksil yang menonjol dari rantai dan membentuk ikatan hidrogen dengan mudah (Rosyadi, et al., 2014). Hal ini mengakibatkan air akan lebih mudah terikat dalam produk seiring peningkatan tepung buah lindur, dan menyebabkan kadar air mie basah semakin meningkat.

\section{Kadar Abu}

Abu merupakan zat organik sisa hasil pembakaran suatu bahan organik. Pengujian kadar abu dimaksudkan untuk mengetahui total abu yang terkandung dalam mie basah dengan substitusi tepung lindur.

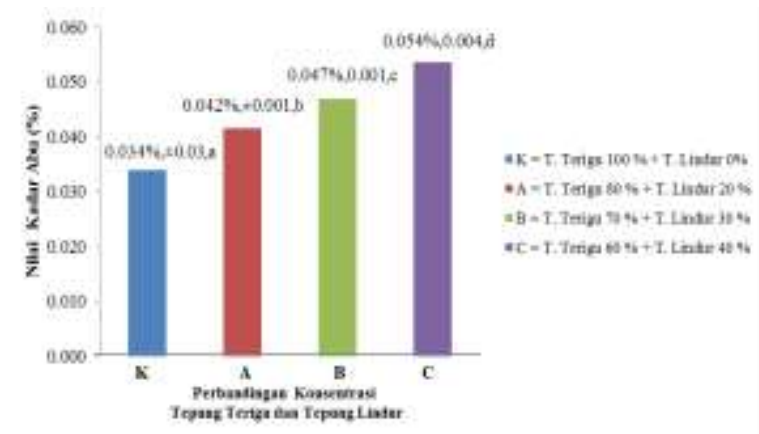

Gambar 2. Rerata Kadar Abu Mie Basah

Hasil analisis sidik ragam menunjukkan bahwa perlakuan substitusi tepung lindur memberikan pengaruh sangat nyata terhadap kadar abu mie basah. Gambar 2. Menunjukkan kadar abu mie basah yang dihasilkan berkisar $0.034 \%$ sampai dengan $0.054 \%$. Kadar abu tertinggi diperoleh pada perlakuan $60 \%$ terigu dengan $40 \%$ lindur (C) yaitu $0.054 \%$, namun tidak berbeda nyata terhadap perlakuan $70 \%$ terigu dengan $30 \%$ tepung lindur (B) yaitu $0.047 \%$ dan perlakuan $80 \%$ terigu dengan $20 \%$ tepung lindur (A) yaitu $0.042 \%$. Kadar abu terendah diperoleh pada 
perlakuan $100 \%$ tergu dengan $0 \%$ tepung lindur $(\mathrm{K})$ yaitu $0.034 \%$. Jika dibandingkan dengan SNI 2987-2015 kadar abu mie basah matang yaitu maksimal $0.05 \%$. Maka perlakuan penambahan konsentrasi tepung lindur 20\%, 30\% dan 40\% masih memenuhi standar SNI.

Hal ini menunjukkan semakin meningkat penggunaan buah lindur menyebabkan kadar abu mie basah semakin meningkat. Kadar abu tepung lindur lebih tinggi yaitu $1.3 \%$ dibandingkan kadar abu tepung terigu $0.46 \%$ (Kent, 1983). Kadar abu merupakan jumlah mineral yang terkandung di dalamnya. Kadar abu pada mie substitusi tepung lindur lebih besar dibandingkan mie basah tanpa tepung lindur. Hal ini menunjukkan bahwa penambahan tepung lindur dapat meningkatkan kadar abu. Nuriana (2009) menyatakan bahwa tepung lindur mengandung mineral. Mineral yang terkadung dalam tepung lindur antara lain kalsium, fosfor, seng, kalium, magnesium, besi, natrium dan tembaga. Kadar abu dalam bahan pangan seperti mie tidak boleh terlalu tinggi, karena kadar abu dalam mie dapat memberikan efek negatif terhadap warna mie (Hou dan Kruk 1998).

\section{Kadar Protein}

Protein merupakan suatu senyawa yang dibutuhkan dalam tubuh manusia sebagai zat pendukung pertumbuhan dan perkembangan. Dalam protein terdapat sumber energi dan zat pengatur jaringan tubuh (Muchtadi, 2010).

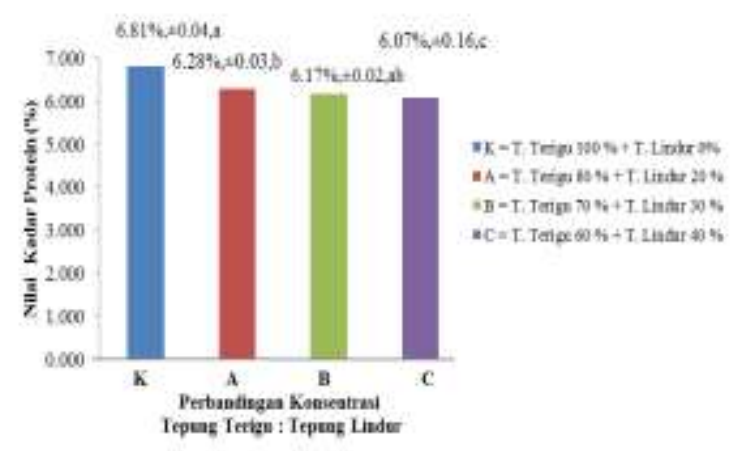

Gambar 3. Rerata Kadar Protein Mie Basah

Hasil analisis sidik ragam menunjukkan bahwa perlakuan substitusi tepung lindur memberikan pengaruh sangat nyata terhadap kadar protein mie basah. Gambar 3. Menunjukkan rata-rata kadar protein mie basah yang dihasilkan berkisar $6.07 \%$ sampai dengan $6.81 \%$. Kadar protein tertinggi diperoleh pada perlakuan $100 \%$ terigu dengan $0 \%$ tepung lindur $(\mathrm{K})$ yaitu $6.81 \%$. Kadar protein terendah diperoleh pada perlakuan $60 \%$ terigu dengan $40 \%$ tepung lindur (C) yaitu $6.07 \%$ namun tidak berbeda nyata terhadap perlakuan $70 \%$ terigu dengan $30 \%$ tepung lindur (B) yaitu $6.17 \%$ dan perlakuan $80 \%$ terigu dengan $20 \%$ tepung lindur (A) yaitu $6.28 \%$. Jika dibandingkan dengan SNI 2987-2015 kadar protein mie basah matang yaitu minimal $6.0 \%$. Maka perlakuan penambahan konsentrasi tepung lindur $20 \%$, 30\% dan 40\% masih memenuhi standar SNI.

Hal ini menunjukkan semakin meningkat penggunaan tepung terigu menyebabkan kadar protein semakin meningkat, hal ini disebabkan karena kadar protein terigu lebih tinggi dibandingkan kadar protein tepung lindur. Kadar protein tepung lindur adalah $4.1 \%$, sedangkan kadar protein terigu adalah $9.61 \%$.

Selain itu pada proses pembuatan mie basah dilakukan proses perebusan yang 
juga menyebabkan penurunan kandungan protein. Proses termal yang terjadi selama perebusan dapat menyebabkan protein terdenaturasi. Denaturasi merupakan proses terpecahnya ikatan hidrogen, interaksi hidrofobik, ikatan garam dan terbentuknya lipatan molekul (Winarno 1992). Kandungan protein di dalam mie basah selain meningkatkan mutu mie basah, juga akan menciptakan adonan yang liat sehingga tidak mudah putus (Fu 2008). Mie ini tergolong layak untuk dikonsumsi sesuai dengan syarat mutu mie basah menurut SNI 2987-2015 dimana nilai minimal kadar air mie basah matang yaitu $6.0 \%$.

\section{Kadar Lemak}

Lemak merupakan salah satu komponen yang dibutuhkan dalam memenuhi kebutuhan tubuh. Kadar lemak tepung sangat berhubungan erat dengan ketahanan produk olahan yang berbahan dasar tepung terhadap ketengikan karna oksidasi lemak (Andriani dan Wirjatmaji, 2012).

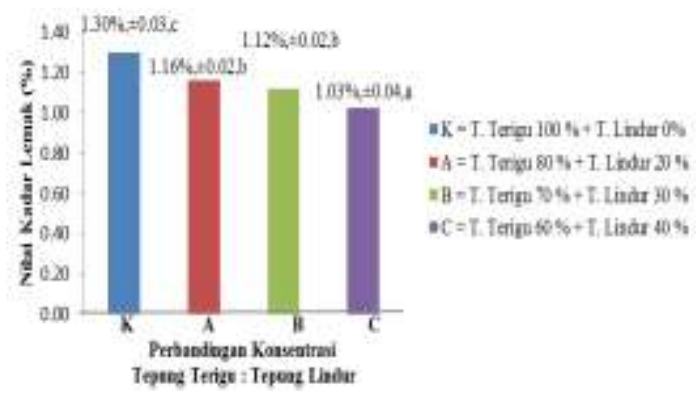

Gambar 4. Rerata Kadar Lemak Mie Basah

Hasil analisis sidik ragam menunjukkan bahwa perlakuan substitusi tepung lindur memberikan pengaruh sangat nyata terhadap kadar lemak mie basah. Gambar 4. menunjukkan bahwa rata-rata kadar lemak mie basah berkisar antara $1.03 \%$ sampai dengan $1.30 \%$. Kadar lemak tertinggi diperoleh pada perlakuan $100 \%$ terigu dengan $0 \%$ tepung lindur $(\mathrm{K})$ yaitu $1.30 \%$ dan perlakuan terendah diperoleh pada perlakuan $60 \%$ terigu dengan $40 \%$ tepung lindur (C) yaitu $1.03 \%$, namun tidak berbeda nyata pada perlakuan $70 \%$ terigu dengan 30\% tepung lindur (B) yaitu $1.12 \%$ dan perlakuan $80 \%$ terigu dengan $20 \%$ lindur (A) yaitu $1.16 \%$.

Semakin meningkat penggunaan terigu menyebabkan kadar lemak mie basah semakin meningkat, hal ini disebabkan karena kadar lemak terigu lebih tinggi dibandingkan kadar lemak tepung lindur. Kadar lemak tepung lindur adalah $1.41 \%$ sedangkan kadar lemak terigu adalah $1.95 \%$. Turunnya kadar lemak disebabkan oleh tepung lindur yang mengandung lemak dengan jumlah yang rendah. Selain itu tingginya kadar air pada mie basah juga menyebabkan turunnya kandungan lemak yang cukup besar. Menurut Winarno (2008) air merupakan salah satu penyebab turunnya kandungan lemak dari suatu bahan pangan. Air dapat menyebabkan terjadinya hidrolisis lemak menjadi gliserol dan asam lemak.

\section{Kadar Karbohidrat}

Karbohidrat merupakan sumber kalori utama, di samping juga mempunyai peranan penting dalam menentukan karakteristik bahan makanan, misalnya rasa, warna, tekstur dan lain-lain (Syarief dan Anies, 1988).

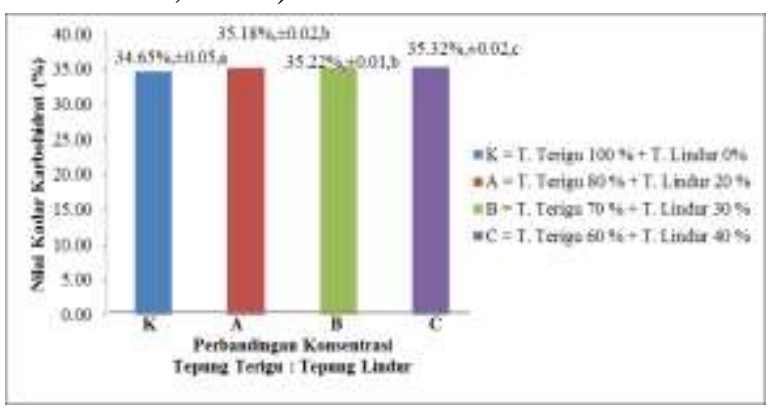

Gambar 5. Rerata Kadar Karbohidrat Mie Basah 
Hasil analisis sidik ragam menunjukkan bahwa perlakuan substitusi tepung lindur memberikan pengaruh sangat nyata terhadap kadar karbohidrat mie basah. Gambar 5, menunjukkan bahwa rata-rata kadar karbohidrat mie basah berkisar antara $34.65 \%$ sampai dengan $35.32 \%$. Kadar karbohidrat tertinggi diperoleh pada perlakuan $60 \%$ terigu dengan $40 \%$ tepung lindur (C) yaitu $35.32 \%$, namun tidak berbeda nyata pada perlakuan $70 \%$ terigu dengan $30 \%$ tepung lindur (B) yaitu 35.22\% dan perlakuan $80 \%$ terigu dengan $20 \%$ lindur (A) yaitu $35.18 \%$. Kadar karbohidrat terendah diperoleh pada perlakuan $100 \%$ terigu dengan $0 \%$ tepung lindur (K) yaitu $34.65 \%$. Semakin tinggi konsentrasi substitusi tepung lindur, semakin tinggi kadar karbohidratnya. Hal ini dikarenakan kandungan karbohidrat pada tepung buah mangrove jenis lindur cukup tinggi yaitu $82.87 \%$. Menurut Fortuna (2005), kandungan karbohidrat buah bakau sebesar 85.1 gram per 100 gram, lebih tinggi dari beras (78.9 gram per 100 gram) dan jagung (63.6 gram per 100 gram). Kandungan karbohidarat pada mie basah dengan penambahan tepung buah lindur lebih tinggi dibandingkan dengan kontrol, sehingga penambahan tepung buah lindur ini dapat menjadi salah satu alternatif untuk mengganti penggunaan tepung terigu.

\section{Uji Hedonik}

\section{Rasa}

Daya terima terhadap bahan pangan juga dipengaruhi oleh rasa. Rasa merupakan faktor yang berpengaruh dalam penerimaan konsumen terhadap produk olahan pangan. Selain faktor tekstur, aroma dan warna, seringkali rasa lebih dominan

dipertimbangkan oleh konsumen dibandingkan sifat mutu lainnya (Tobri, 2006).

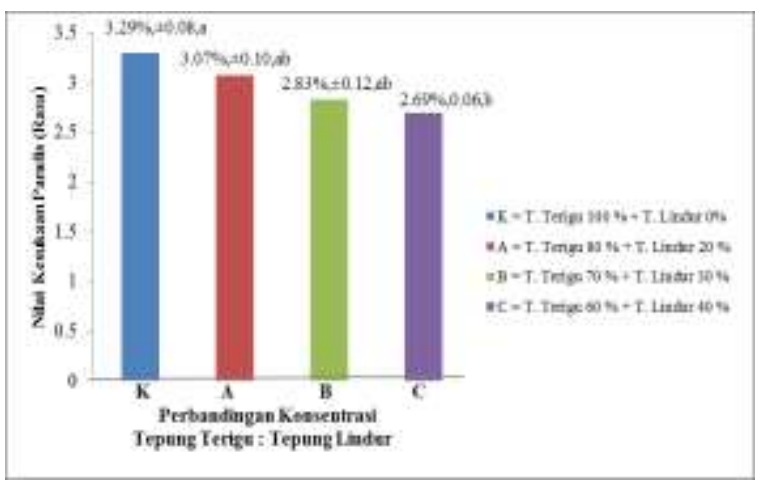

Gambar 6. Rerata Kesukaan Panelis (Rasa)

Hasil analisis sidik ragam menunjukkan bahwa perlakuan substitusi tepung lindur memberikan pengaruh sangat nyata terhadap rasa mie basah. Gambar 6 . Menunjukkan bahwa rata-rata tingkat kesukaan panelis terhadap rasa mie basah, berkisar antara 2.69 sampai dengan 3.29 yang berarti suka.

Berdasarkan hasil penelitian menunjukkan bahwa tingkat kesukaan panelis cenderung lebih menyukai cita rasa mie basah yang tidak dilakukan substitusi tepung lindur. Penggunaan tepung buah lindur pada pembuatan mie basah mempengaruhi rasa mie basah yang dihasilkan. Semakin banyak konsentrasi tepung lindur maka tingkat kesukaan panelis terhadap rasa semakin menurun. Hal ini disebabkan karena tepung lindur memiliki cita rasa yang khas. Kandungan senyawa tanin pada tepung buah lindur sangat berpengaruh terhadap rasa mie basah. Pada tumbuhan, tanin biasanya memberikan rasa sepat (Sa'adah et al. 2010). Sehingga mengakibatkan rasa sepat pada produk. 


\section{Warna}

Warna merupakan faktor mutu yang paling menarik perhatian konsumen, Warna merupakan atribut kualitas yang paling penting. Bersama-sama dengan tekstur dan rasa, warna berperan dalam penentuan tingkat penerimaan suatu makanan. Warna memberikan kesan apakah makanan tersebut disukai atau tidak (Meilgard et al., 2006).

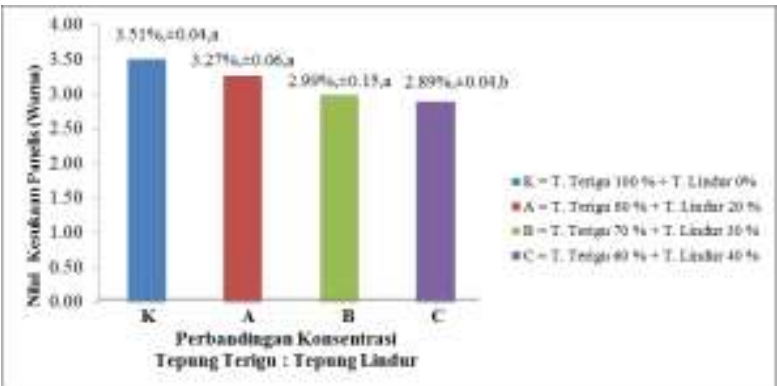

Gambar 7. Rerata Kesukaan Panelis (Warna)

Hasil analisis sidik ragam menunjukkan bahwa perlakuan substitusi tepung lindur memberikan pengaruh sangat nyata terhadap warna mie basah. Gambar 7. Menunjukkan bahwa tingkat kesukaan panelis terhadap warna mie basah berkisar antara 2.89 sampai dengan 3.51 yang berarti panelis memberikan penilaian suka.

Berdasarkan hasil analsis diketahui bahwa skor uji organoleptik warna mie basah cenderung menurun dengan semakin bertambahnya konsentrasi tepung lindur artinya panelis lebih menyukai warna mie basah tanpa substitusi tepung lindur. Dari hasil penilaian menunjukkan bahwa tidak ada penolakan panelis terhadap warna mie basah, penilaian organoleptik terhadap warna mie basah secara umum menunjukkan rata-rata panelis memberikan penilaian suka pada semua formula. Hal ini menunjukkan berdasarkan penilaian warna semua formula mie basah masih dapat diterima oleh panelis.

Berdasarkan hasil penelitian menunjukkan bahwa semakin tinggi substitusi tepung lindur, semakin rendah tingkat kesukaan panelis terhadap warna mie basah yang dihasilkan. Hal ini disebabkan karena tepung buah lindur yang dihasilkan dalam penelitian ini memiliki warna alami kuning kecoklatan. Warna pada tepung buah lindur dapat dipengaruhi oleh proses pengolahan ataupun pigmen yang terkandung di dalamnya. Pigmenpigmen yang penting dapat berupa klorofil, karotenoid, antosianin, antoxantin serta tannin (Winarno 2008). Pada buah lindur terdapat tanin sehingga secara kasat mata warna tepung yang dihasilkan agak kecoklatan. Berdasarkan penelitian yang dilakukan Sulistyawati et. al (2012) kadar tanin yang terkandung dalam tepung buah lindur sebesar $0.192 \%$ sudah memenuhi syarat sebagai bahan pangan karena kadar tanin maksimal dalam bahan pangan makanan yang ditetapkan ADI adalah 560 $\mathrm{mg} / \mathrm{kg}$ berat badan/hari. Tanin disebut juga asam tanat dan asam galotanat. Tanin dapat tidak berwarna hingga berwarna kuning atau coklat. Kandungan tanin pada tepung buah lindur dapat membentuk warna kuning atau coklat. Oksidasi tanin dapat terjadi pada tahap pengeringan dengan oven atau pengeringan dengan sinar matahari selama proses pembuatan tepung.

Warna kecoklatan yang terbentuk juga berhubungan dengan reaksi pencoklatan enzimatis dari senyawa fenolik yang terkandung dalam buah lindur maupun reaksi pencoklatan non enzimatis terutama reaksi Maillard. Berlangsungnya kedua tipe reaksi tersebut sangat dipengaruhi oleh suhu pengeringan yang digunakan. Reaksi pencoklatan enzimatis 
terhadap senyawa fenolik banyak dikatalisis oleh enzim katekol oksigenase (dalam bentuk polifenol oksidase) yang keluar apabila bahan terluka. Pada tahap awal terjadi reaksi hidroksilase monofenol menjadi difenol selanjutnya oksidasi difenol menjadi kuinon yang berkontribusi terhadap warna gelap, kuning, oranye, dan coklat (Sulistiyawaty et al.,2012).

Selain reaksi enzimatis, timbulnya warna coklat juga disebabkan oleh reaksi non enzimatis akibat proses pemanasan pada proses pembuatan tepung buah lindur. Proses pemanasan dapat menyebabkan terjadinya reaksi Maillard antara gula pereduksi dari pati dan asam amino (gugus amino primer) dari protein yang menghasilkan pembentukan warna coklat. Pada reaksi Maillard gugus karbonat dari glukosa bereaksi dengan nukleofilik gugus amino dari protein yang menghasilkan warna khas (coklat) (Sulistiyawaty et al., 2012). Kadar abu juga mempengaruhi warna, semakin tinggi kadar abu nya maka semakin cokelat warna yang dihasilkan (Martunis, 2012). Bandaranayake et al. (2002) menyatakan bahwa kadar abu yang tinggi pada bahan tepung kurang disukai karena cenderung memberi warna gelap pada produknya. Semakin rendah kadar abu pada produk tepung akan semakin baik, karena kadar abu selain mempengaruhi warna akhir produk juga akan mempengaruhi tingkat kestabilan adonan.

\section{Aroma}

Aroma merupakan sifat mutu yang sangat cepat memberikan kesan bagi konsumen, karena aroma merupakan faktor yang sangat berpengaruh pada daya terima konsumen terhadap suatu produk (Tobri, 2006).

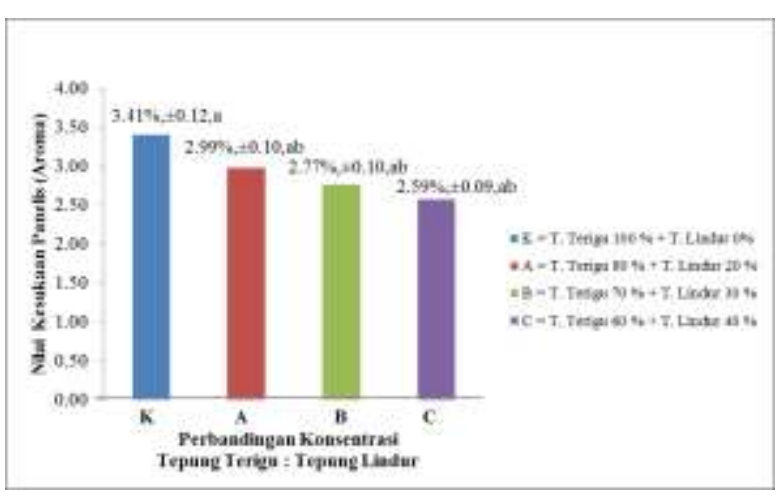

Gambar 8. Rerata Kesukaan Panelis (Aroma)

Hasil analisis sidik ragam menunjukkan bahwa perlakuan substitusi tepung lindur memberikan pengaruh sangat nyata terhadap aroma mie basah. Gambar 8 . Menunjukkan rata-rata tingkat kesukaan panelis terhadap aroma mie basah berkisar antara 2.59 sampai dengan 3.41 yang berarti suka. Semakin tinggi konsentrasi tepung lindur tingkat kesukaan panelis terhadap aroma mie basah semakin menurun. Hal tersebut disebabkan karena tepung lindur memiliki aroma khas tepung lindur sehingga semakin banyak penambahan tepung lindur yang digunakan maka aroma tepung lindur semakin terasa sepat. Menurut Harison dan Dake (2005) tepung lindur mengandung senyawa fenolik senyawa fenolik merupakan senyawa yang banyak ditemukan pada tumbuhan. Fenolik memiliki cincin aromatik satu atau lebih gugus hidroksi ( $\mathrm{OH}-)$ dan gugus - gugus lain penyertanya. Senyawa ini diberi nama berdasarkan nama senyawa induknya, fenol. Senyawa fenol kebanyakkan memiliki gugus hidroksil lebih dari satu sehingga disebut polifenol.

\section{Tekstur}

Tesktur merupakan sifat yang sangat penting, baik dalam makanan segar maupun hasil olahan. Tekstur dan 
konsistensi bahan akan mempengaruhi cita rasa suatu bahan.

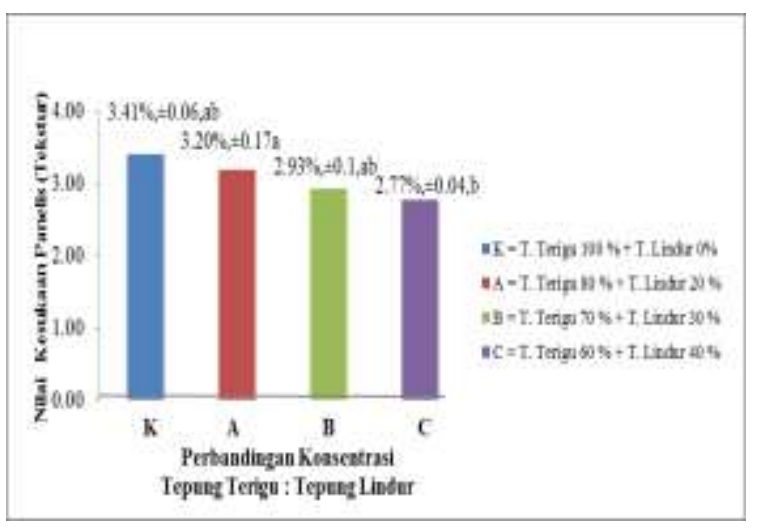

Gambar 9. Rerata Kesukaan Panelis (Tekstur)

Hasil analisis sidik ragam menunjukkan bahwa perlakuan substitusi tepung lindur memberikan pengaruh sangat nyata terhadap tekstur mie basah.

Gambar 9. menunjukkan rata-rata tingkat kesukaan panelis berkisar antara 2.77 sampai dengan 3.41 yang berarti suka. Hal ini menunjukkan berdasarkan penilaian tekstur semua formula mie basah masih dapat diterima oleh panelis.

Mie basah dengan persentase tepung lindur lebih banyak, mengalami penuruan mutu pada segi tekstur. Hal ini terjadi karena mie basah dengan persentase tepung lindur lebih banyak mempunyai kandungan protein lebih sedikit. Peran protein dalam mie basah yaitu membentuk tekstur menjadi lebih kenyal. Komponen protein yang hanya ada dalam tepung terigu yaitu gluten. Gluten bersifat elastis sehingga akan mempengaruhi kekenyalan pada produk mie basah (Suprapti,2005), sehingga jika kandungan protein dalam mie basah substitusi tepung lindur terlalu rendah akan menghasilkan mie yang tidak kenyal dan mudah putus. Tekstur tepung lindur yang digunakan tidak sehalus tepung terigu sehingga tekstur mie basah yang dihasilkan masih terasa kasar. Semakin tinggi konsentrasi tepung buah lindur yang digunakan, menghasilkan tekstur mie basah yang kurang disukai.

\section{Simpulan}

Berdasarkan hasil penelitian dan pembahasan dapat disimpulkan bahwa terdapat pengaruh substitusi tepung buah mangrove jenis lindur (Bruguiera gymnorrhiza) terhadap kadar air, abu, protein, lemak, karbohidrat dan hasil organoleptik yaitu rasa, warna, tekstur, aroma dengan perlakuan terbaik berdasarkan metode MPE adalah perlakuan A (Tepung terigu $80 \%+$ Tepung Lindur $20 \%$ ).

\section{Daftar Pustaka}

Andriani, M \& Wirjatmaji, B. 2012. Pengantar Gizi masyarakat. Jakarta: Kencana Prenada Media Group.

Astawan, M. 2006. Membuat mie dan bihun. Jakarta: Penebar Swadaya.

Astina, N. 2007. Pembuatan Mie Basah dalam Penambahan Wortel (Daucus carota L.). Skripsi. Medan: Universitas Sumatera Utara.

Bandaranayake, W.M., 2002. Traditionl and medical uses of mangroves and salt marshes, 2, 133-148

Duke N.C., \& James AA. 2006. Bruguiera gymnorrhiza (large-leafed mangrove). Species Profiles for Pacific Island Agroforestry

Fortuna, James de. 2005. Ditemukan Buah Bakau Sebagai Makanan Pokok. http:www.Tempointteraktif.com 
JPTP Jurnal Pendidikan Teknologi Pertanian

Fu, B.X. 2008. Asian noodles: history, classification, raw materials, and processing. Food Res. Int, 41(9), $88-90$.

Hamzah. 2017. Analisis kandungan tepung buah mangrove jenis lindur (Bruguerra sp) sebagai alternatif bahan pangan lokal. Skripsi. Makassar: Universitas Negeri Makassar.

Harrison \& Dake. 2005. An Expeditions High Yielding Construction of the Food Aroma Compounds 6-acetyl 1,2,3,4-tetradydropyridine and 2acetyl-1pyrraline. Journal Org.Chem. 70(26), 10872-10874

Hou, \& Kruk. 1998. Mie . Juli 10, 2019. http://id.shvoong.com.

Juniawati. 2003. Optimasi Proses Pengolahan $\mathrm{Mi}$ Jagung Instan Berdasarkan Preferensi Konsumen. Skripsi. Bogor: IPB.

Kent, N.L. 1983. Technology of cereal. Sydney: Pergamon Press.

Koswara. 2009. Teknologi pengolahan mie. $\begin{array}{lll}\text { Februari } & 1,\end{array}$ eBookPangan.com.

Martunis. 2012. Pengaruh Suhu dan Lama Pengeringan terhadap Kualitas Pati Kentang Varietas Granola. Jurnal Teknologi dan Industri Pertanian Indonesia. 4(3), 26-30

Meilgaard M, Civille G.V, \& Carr B.T. 2006. Sensory evaluation techniques. Boca Raton: CRC.

Muchtadi, Deddy. 2010. Kedelai: komponen bioaktif untuk kesehatan. Bandung: Alfabeta

Nuriana W. 2009. Pemanfaatan limbah biji (beton) nangka sebagai tepung dan keripik. Jurnal Agritek 9(2): 1-7.
Volume 6, tahun 2020

Rosyadi, E., S.B. Widjarnako, \& D.W. Ningtyas. 2014. Pembuatan lempeng buah lindur (Bruguiera gymnorrhiza) dengan penambahan tepung ubi kayu (Manihot esculenta crantz). Jurnal Pangan dan Agroindustri, 2 (4), 10-17.

Sadana. D. 2007. Buah aibon di biak timur mengandung karbohidrat tinggi. Situs Resmi Pemda Biak Num for news_.html.

Sa'adah et al. 2010. Isolasi dan identifikasi senyawa tanin dari daun belimbing wuluh (Averrhoa blimbi L.) Skripsi. Malang: UIN

Sulistyawati., Wignyanto., \& Kumalaningsih, S. (2012). Produksi tepung buah lindur (Bruguiera gymnorrhiza Lamk.) rendah tanin dan hen sebagai bahan pangan alternatif. Jurnal Teknologi Pertanian, 13(3), 187-198.

Suprapti, L. 2005. Teknologi Pengolahan Pangan Tepung Tapioka dan Pemanfaatanya. PT. Gramedia Pustaka: Jakarta.

Syarief, R., dan I. Anies. 1988. Pengetahuan Bahan untuk Industri Pertanian. Jakarta: Mediyatama Sarana Perkasa.

Tobri, M. 2006. Kualitas fisik dan organoleptik daging ayam broiler yang ransumnya diberi penambahan minyak ikan yang mengandung omega-3. Skripsi. Bogor: Institut Pertanian Bogor.

Winarno, F.G. 1992. Kimia pangan dan gizi. Jakarta: Gramedia Pustaka Utama.

Winarno, F.G. 2002. Kimia pangan dan gizi. Jakarta: Gramedia Pustaka Utama. 
Winarno, F.G. 2008. Kimia pangan dan gizi. Bogor: Mbrio PressBiotekind 
Halaman Ini Sengaja dikosongkan 